\title{
Nitrogen Solubility and Functional Properties of Roselle Seed Flour
}

\author{
Karma Bako Rimamcwe, U.D. Chavan*, G.H. Pawar and R.S. Gaikwad \\ Department of Food Science and Technology, Mahatma Phule Krishi Vidyapeeth, \\ Rahuri, Maharashtra, India \\ *Corresponding author
}

\section{A B S T R A C T}

\begin{tabular}{|c|c|}
\hline & \multirow{4}{*}{$\begin{array}{l}\text { Roselle seeds were procured from the local market and decortication and } \\
\text { sprouting treatments were given to them and then seed flour utilized for the } \\
\text { study of nitrogen solubility and functional properties. Studies on nitrogen } \\
\text { solubility showed that there is no significant difference between sprouted } \\
\text { and un-sprouted Roselle seed flour treatments, both treatments had the } \\
\text { lowest solubility at } \mathrm{pH} 4.0 \text { and maximum at } \mathrm{pH} 12.0 \text {. Sprouting and } \\
\text { decortication of Roselle seeds showed better functional properties for } \\
\text { utilization of Roselle seed flour in various food products. Studies on } \\
\text { sedimentation values for both decorticated sprouted and raw seed flour } \\
\text { showed that inclusion up to } 25 \% \text { can be utilized as all-purpose flour. The } \\
\text { sprouted treatments had shown better quality. }\end{array}$} \\
\hline $\begin{array}{l}\text { Roselle seeds, } \\
\text { Sprouting, } \\
\text { Decortication, } \\
\text { Functional } \\
\text { properties, } \\
\text { Sedimentation } \\
\text { value, Nitrogen } \\
\text { solubility. }\end{array}$ & \\
\hline Article Info & \\
\hline $\begin{array}{l}\text { Accepted: } \\
\text { 14 June } 2017 \\
\text { Available Online: } \\
\text { 10 August } 2017\end{array}$ & \\
\hline
\end{tabular}

\section{Introduction}

Roselle (Hibiscus sabdariffa Linn.) is a tropical plant belonging to the Family Malvaceae and widely cultivated for its jute like fiber in India, the East Indies, Nigeria and to some extent in tropical America (Yayock, 1988). A woody sub-shrub growing 7-8 feet (2-2.5m) tall, acting as annual or perennial, takes about six months to mature.

The mature plants are highly drought resistant but may require water during dry periods when soil moisture is depleted to the point where wilting occurs. Roselle requires a chalky, loamy and peat-rich soil with $\mathrm{pH}$ of 7.6-9.0; and grows best in weakly alkaline soil (Myfolia, 2016). The seeds of this crops from which edible oil could be extracted are being wasted in its production area after the farmers might have taken the quantity needed for the next planting season for the calyces production (Bamigboy et al., 2009; Emmy Hainida et al., 2008). The seeds have been found to be a source of highly valued vegetable oil with properties similar to that of crude olive. In terms of their oil content, the seeds of $H$. sabdariffa are richer in lipids (22\%) than most well-known seed oil such as those derived from Cotton (13\%), Soybean (14\%) and Palm fruit (20\%) (Nzikou et al., 2012; Karma and Chavan, 2016; Karma and Chavan, 2017). 
The lipid profile indicated Roselle seed oils are good sources of phospholipids, the levels of which compare favourably with that of Soybean oil (1.5 to 2.5\%) (Gunstone, 2002). This high level of phospholipids may contribute to the stability and antioxidant activity of the oils. Antioxidant compounds are gaining importance due to their dual role in food and pharmaceutical industries as lipid stabilizers (Ramadan and Morsel, 2004). Nutritionally important antioxidants such as tocopherols improve the stability of oil. In a study, Roselle seed oil (RSO) and Roselle seed extract (RSE) was mixed with Sunflower oil, respectively to monitor degradation rate and investigate antioxidant activity during accelerated storage. The antioxidant activity was found to stabilize Sunflower oil of various samples and in the order of RSE > RSO > Tocopherol > Sunflower oil (Nyam et al., 2012).

Roselle seed oil are richer in carotenoids than expensive oils like niger (Guizotia abyssinica) seed oil $(70.2 \pm 0.03 \mathrm{mg} \beta$-carotene $/ 100 \mathrm{~g})$ and coriander (Coriander sativum) seed oil (89.2 $\pm 0.05 \mathrm{mg} \quad \beta$-carotene/100g) (Ramadan and Morsel, 2004). Carotenoids are important ingredients in cosmetic industries due to their antioxidant activity and protective effect on the skin (Platon, 1997). Therefore, Roselle seeds oil has good potential for utilization in the Cosmetic Industry. The proximate composition of whole Roselle seeds indicated that, seeds contained relatively high fat and protein (as \%N $x$ 6.25; $20.97 \%$ and $29.61 \%$ respectively). The physico-chemical parameters of crude oil extracted from Roselle seeds by soaking at room temperature (cold extraction) indicated the oils had 1.4674 refractive index; 0.078 (at 420nm) yellowgreenish colour, $0.78 \%$ acidity, 198.82 saponification value, 97.62 ( $\mathrm{g}$ of $\mathrm{I}_{2} / 100 \mathrm{~g}$ oil) iodine value; $1.52 \%$ unsaponifiable matter; 4.82 (Meq $0_{2} / \mathrm{Kg}$ oil) peroxide value; $6.21 \mathrm{p}$ anisidine value; and 15.85 totox number. Gas Liquid Chromatography technique has been developed for identification and quantitative determination of total unsaturated and saturated fatty acids. This technology showed that Roselle crude oil had $73.40 \%$ unsaturated and $26.57 \%$ saturated fatty acids respectively. Major fatty acid found was oleic acid (38.46\%) followed by linoleic $(33.25 \%)$ and Stearic $(5.79 \%)$. Stability of crude Roselle seed oil against oxidation during the accelerated storage of oil indicated that the crude oil induction period to be 10 days at $65^{\circ} \mathrm{C}$. The relatively high fat content of the seeds and high protein content of resulted meal beside the relatively high oxidation stability of Roselle suggest that Roselle seeds could be a novel and economic source of healthy edible fat and for other food industry applications.

Protein fractions, proteins isolates or concentrates obtained from Roselle seeds might be an alternative source of low cost protein substitute in dietary supplement in ingredients for food industry. This may reduce the heavy dependence on conventional sources such as animal, fish and soybean proteins. The ease of cultivation gives Roselle seed economic advantage over majority of oil producing seeds as a low cost cultivar with high value source of nutrition. The high value and cheap plant protein source is a suitable alternative for animal protein especially in a vegetarian society such as India and other countries too.

At present, there are very few reports on harnessing the bio-nutritional potential of Roselle seeds in value added products (Nyam et al., 2014). Adding cereals with complementary nutritive profiles, such as Roselle seeds, may yield a more complete enrich food source (Okafor et al., 2002; Arshad et al., 2007; Bala et al., 2015; Wani et al., 2015). Hence, the aim of this study was to investigate the nitrogen solubility and functional properties of the Roselle seeds floor. 


\section{Materials and Methods}

The raw seed materials, ingredients and chemicals used in this study were procured from the local market. Roselle (Hibiscus sabdariffa Linn.) seeds and wheat were sourced from vegetable markets in Ahmednagar, Maharashtra State, India.

\section{Germination}

The cleaned seeds were soaked for 6 hours to activate the process of germination, after which the seeds were washed and allowed to drain.

The drained seeds were then spread on a damped cloth in a perforated container with water sprinkled occasionally in a dark room to activate germination for a another 12 hour period; then gently washed and spread sparsely to dry under fan at ambient temperature to preserve its nutritive value, packed in a HDPE bag and stored in a cool dry place until used.

\section{Flour types}

The various forms of Roselle seeds flour were prepared such as un-sprouted Whole Roselle Seed Flour (UWRSF); Un-sprouted Decorticated Roselle Seed Flour (UDRSF); Sprouted Whole Roselle Seed Flour (SWRSF); and Sprouted Decorticated Roselle Seed Flour (SDRSF). Then these flours were used for various parameters studied under different experiments.

\section{Nitrogen solubility}

Nitrogen solubility of the sample flour was determined according to the method of Naryana and Rao (1982) in the $\mathrm{pH}$ range 2 to 12, using 1 gram Roselle seed flour sample to water ratio of 1:60 and shaking for 2 hour at room temperature. The $\mathrm{pH}$ of the solution was adjusted using $0.1 \mathrm{~N} \mathrm{NaOH}$ and $0.1 \mathrm{~N} \mathrm{HCl}$.
After extraction the suspension was centrifuged at $3,000 \times \mathrm{g}$ for $20 \mathrm{~min}$ at room temperature $(25 \pm 2)$ and Nitrogen in the supernatant was estimated by the microkjeldahl method. The nitrogen extracted was expressed as percent of flour nitrogen content.

Nitrogen $(\%)=\frac{\left(\begin{array}{c}\text { Sample_Blank } \\ \text { titre }\end{array}\right)}{\begin{array}{c}\text { Digestuse for } \\ \text { distillation }\end{array}} \times \frac{\begin{array}{c}\text { Volume } \\ \text { made }\end{array}}{\begin{array}{c}\text { Weight of } \\ \text { sample (g) }\end{array}} \times \begin{gathered}\text { Normality } \\ \text { of acid }\end{gathered} \times \frac{14.007}{1} \times \frac{100}{1000}$

Soluble Nitrogen $(\%)=\frac{\mathrm{mg} \text { of Nitrogen in Extract }}{\mathrm{mg} \text { of Nitrogen in Sample }} \times 100$

\section{Functional properties}

The functional properties of the pretreatments of Roselle seeds flour where studied under the following headings.

\section{Oil Holding Capacity (OHC)}

This property was determined using the method of Vazquez-Ovando et al., (2009) as reported by Nyam et al., (2012) with slight modifications; $1 \mathrm{~g}$ each of the samples $\left(\mathrm{W}_{0}\right)$ was weighed into pre weighed centrifuge tubes $\left(T_{1}\right)$ and mixed thoroughly with $10 \mathrm{~mL}$ $\left(\mathrm{V}_{1}\right)$ of soybean refined pure oil using a vortex mixer.

The sample was allowed to stand for 30min at room temperature. The sample was then centrifuged at $10,000 \mathrm{x} \mathrm{g}$ for $30 \mathrm{~min}$. The supernatant was then completely drained and the final wet weight of the sample plus tube was measured and recorded $\left(\mathrm{T}_{2}\right)$. The oil holding capacity $(\mathrm{OHC})$ of the flour samples were calculated using the equation:

$$
\mathrm{OHC}(\mathrm{g} / \mathrm{g})=\frac{\left[\left(\mathrm{T}_{2}-\mathrm{T}_{1}\right)-\mathrm{W}_{0}\right]}{\mathrm{W}_{0}}
$$

Result was expressed as gram of oil absorbed per gram of flour sample. Analysis was performed in triplicate. 


\section{Water Holding Capacity (WHC)}

To determine the water holding capacity (WHC) of Roselle seed sample flours using the method from Rosell et al., (2009) with slight modification. Triplicate samples (1g) were mixed separately with $10 \mathrm{~mL}$ distilled water in centrifuge tubes and vortexed for 1 minute. The set up was kept at room temperature for $30 \mathrm{~min}$ and then centrifuged at $10,000 \mathrm{x} \mathrm{g}$ for $10 \mathrm{~min}$. The supernatant was filtered with Whatman number 1 filter paper and the final wet weighted sample was subjected to oven-dried at $105{ }^{0} \mathrm{C}$ until constant weight. The dried sample was cooled in a dessicator and the mass weighed and recorded. The Water Holding Capacity was estimated using the equation:

Wet weight (g) - Dry weight (g)

WHC $(\mathrm{g} / \mathrm{g})=$

\section{Foaming capacity and foaming stability}

Foaming Capacity (FC) was determined in triplicate using the method described by Makri et al., (2005), with modifications. Concentrations of $10 \%$ sample flours were prepared in de-ionized water and adjusted to $\mathrm{pH} 7.4$ with $1.0 \mathrm{~N} \mathrm{NaOH}$ and $1.0 \mathrm{~N} \mathrm{HCl}$. The volume of $100 \mathrm{~mL}\left(\mathrm{~V}_{1}\right)$ of the flour suspension was blended for 3 min using a high speed blender and immediately poured into a $250 \mathrm{~mL}$ graduated cylinder, and the volume of foam $\left(V_{F}\right)$ was recorded. Foaming capacity was calculated using the equation.

$\mathrm{FC}=\frac{\mathrm{V}_{\mathrm{F}}}{\mathrm{V}_{1}}$

Foam stability was determined by measuring the fall in volume of the foam after $60 \mathrm{~min}$.

\section{Emulsifying capacity}

Emulsifying capacity was determined using the method described by AACC (2000a) with modifications. $1 \mathrm{~g}$ of each sample was transferred into a $250 \mathrm{~mL}$ beaker to which a mixture of $50 \mathrm{~mL}$ of $0.5 \mathrm{~N} \mathrm{NaCl}$ solution and $50 \mathrm{~mL}\left(\mathrm{~V}_{\mathrm{o}}\right)$ of soybeans pure oil was added. The mixture was homogenized using a motorized stirrer (Wiggen Hauser Homogeniser) to make an emulsion for 2 minutes. The emulsion mixture was immediately transferred into centrifuge tube maintained in a water bath at $90{ }^{0} \mathrm{C}$ for 10 minutes, then centrifuged at $10,000 \mathrm{x} \mathrm{g}$ for 10 minutes. The volume of oil released after centrifugation was recorded as $\left(\mathrm{V}_{\mathrm{R}}\right)$. Analysis was performed in triplicate. The emulsifying capacity was calculated as:

$\mathrm{EC}(\mathrm{ml} / \mathrm{g})=\frac{\mathrm{V}_{0}-\mathrm{V}_{\mathrm{r}}}{-------}$

Where:

$\mathrm{V}_{0}=$ Volume of oil to form emulsion

$\mathrm{V}_{\mathrm{r}}=$ Volume of oil released after centrifugation

$\mathrm{W}_{\mathrm{s}}=$ Weight of sample

\section{Sedimentation value}

Sedimentation value of the composite flours (Roselle seed flour: wheat flour) was determined using the standard method AACC (2000b).

The test is based on the fact that gluten protein absorbs water and swells considerably when treated with lactic acid in the presence of sodium dodecyl sulphate (SGS). The volume of sediment depends on the extent of swelling of gluten protein.

\section{Experimental design}

Based on review of literature and preliminary studies, the experimental work plan was 
prepared and experimental parameters were identified.

The detailed work plan, treatments variables and experimental design are clearly outlined. The data obtained were statistically analyzed by CRD (Completely Randomized Design) as given by Panse and Sukhatme (1967).

\section{Results and Discussion}

\section{Nitrogen solubility}

The results of nitrogen solubility of Roselle seed flour affected by pre-treatments are presented in table 1 and figure 1 . These results indicated that the iso-electric point of the Roselle seed flour protein is 4.0. As the $\mathrm{pH}$ decreases from 4.0 or increases from this point solubility increases. At $\mathrm{pH} 4.0$ Roselle seed flours' nitrogen solubility was minimum (Figure 1).

This minimum solubility of Roselle seed flours protein helps for isolating protein fractions for other biochemical components for further studies. These results are in agreement with literature (Salunkhe et al., 1992). These results are also similar to the results of most of the legume proteins. This indicates that the properties of the nitrogen present in the Roselle seed flour proteins are similar to the legume proteins.

Therefore, it might have wide scope to use these nutritious proteins in various food formulations and get higher protein content in the new food item prepared with Roselle seed flour. The sprouted decorticated Roselle seed flours' protein showed higher solubility than the un-sprouted decorticated Roselle seed flour (Figure 1). These results indicated that sprouting treatment gave good results for protein solubility for utilization in various food products.
The sprouting of seeds also enhances the vitamin availability in the seed flour.

\section{Functional properties}

The effects of pre-treatments on the functional properties of Roselle seeds were studied. The results are outlined in table 2.

The Pre-treatments to Roselle seeds showed significant difference $(p<0.05)$ in the functional properties. Mostly the sprouted treatment gave very good functional properties which are beneficial for new food product preparation.

\section{Oil holding capacity}

The flour prepared from un-sprouted decorticated, sprouted whole, and sprouted decorticated Roselle seeds were shown higher oil holding capacity than the control.

\section{Water holding capacity}

All flours showed similar water holding capacity. This indicates that all flours have similar properties for water holding with and without seed coat.

\section{Emulsifying capacity}

The un-sprouted decorticated Roselle seed flour showed higher emulsifying capacity followed by sprouted decorticated Roselle seed flour and lowest by sprouted whole Roselle seed flour.

\section{Foaming capacity}

All treated Roselle seed flours showed higher foaming capacity than the control due to sprouting or due to cotyledons flour. 
Table.1 Effect of $\mathrm{pH}$ on nitrogen solubility

\begin{tabular}{|c|c|c|}
\hline \multirow{2}{*}{$\mathbf{p H}$} & \multicolumn{2}{|c|}{ \% Nitrogen Solubility } \\
\cline { 2 - 3 } & UDRSF & SDRSF \\
\hline 2 & 7.6 & 8.2 \\
\hline 4 & 6.6 & 6.3 \\
\hline 6 & 8.0 & 7.9 \\
\hline 8 & 9.8 & 9.6 \\
\hline 10 & 11.3 & 11.0 \\
\hline 12 & 12.4 & 11.9 \\
\hline S.E.( $($ ) & 0.03 & 0.04 \\
\hline CD at 5\% & 0.09 & 0.12 \\
\hline CV $(\%)$ & 0.73 & 0.95 \\
\hline
\end{tabular}

*Each value is an average of three determinations. NB: UDRSF (Un-sprouted Decorticated Roselle Seed Flour); SDRSF (Sprouted Decorticated Roselle Seed Flour).

Table.2 Effects of pre-treatments on the functional properties of Roselle seed flour

\begin{tabular}{|l|c|c|c|c|c|}
\hline \multicolumn{1}{|c|}{ Treatments } & $\begin{array}{c}\text { Oil Holding } \\
\text { Capacity } \\
\text { (OHC), g/g }\end{array}$ & $\begin{array}{c}\text { Water Holding } \\
\text { Capacity } \\
\text { (WHC), g/g }\end{array}$ & $\begin{array}{c}\text { Emulsifying } \\
\text { Capacity (EC), } \\
\mathrm{ml} / \mathrm{g}\end{array}$ & $\begin{array}{c}\text { Foaming } \\
\text { Capacity, } \\
\%\end{array}$ & $\begin{array}{c}\text { Foam } \\
\text { Stability } \\
\%\end{array}$ \\
\hline UWRSF(control) & 0.724 & 2.10 & 8.12 & 8.00 & 10 \\
\hline UDRSF & 0.734 & 1.90 & 9.90 & 18.00 & 10 \\
\hline SWRSF & 0.782 & 2.20 & 7.37 & 10.00 & 10 \\
\hline SDRSF & 0.794 & 2.00 & 8.45 & 20.00 & 10 \\
\hline S.E. $( \pm)$ & 0.01 & 0.09 & 0.04 & 0.22 & \\
\hline CD at 5\% & 0.02 & 0.27 & 0.13 & 0.68 & \\
\hline CV $(\%)$ & 1.31 & 7.62 & 0.88 & 2.77 & \\
\hline
\end{tabular}

Each value is an average of six determinations. NB: UWRSF (Un-sprouted Whole Roselle Seed Flour); UDRSF (Un-sprouted Decorticated Roselle Seed Flour); SWRSF (Sprouted Whole Roselle Seed Flour); SDRSF (Sprouted Decorticated Roselle Seed Flour).

Table.3 Effects of Roselle Seed flour in composite formulation on Sedimentation value of wheat flour

\begin{tabular}{|l|c|c|}
\hline \multirow{2}{*}{ Treatment } & \multicolumn{2}{|c|}{ Sedimentation Value } \\
\cline { 2 - 3 } Roselle Flour : Wheat flour & SWRSF & SDRSF \\
\hline $0: 100($ Control) & 44.00 & 44.00 \\
\hline $10-90$ & 35.25 & 34.50 \\
\hline $15-85$ & 33.00 & 31.50 \\
\hline $20-80$ & 29.75 & 29.25 \\
\hline $25-75$ & 27.75 & 26.25 \\
\hline S.E. $( \pm)$ & 0.61 & 0.57 \\
\hline CD at 5\% & 1.84 & 1.72 \\
\hline CV $(\%)$ & 3.59 & 3.44 \\
\hline
\end{tabular}

*Sprouted Whole Roselle Seed (SWRSF), Sprouted Decorticated Roselle Seed flour (SDRSF), Sedimentation values range (Zeleny, 1947): 60 and 0ver - entirely hard wheat high protein content over 14 per cent; 40 to 59 almost entirely medium wheat protein content from 12 to $14 \% ; 20$ to 39 - low protein content hard weight best use as an all-purpose flour; less than 20 - almost entirely of soft wheat but may contain hard wheat. 
Fig.1 Nitrogen solubility profile of Roselle seed flour treatments

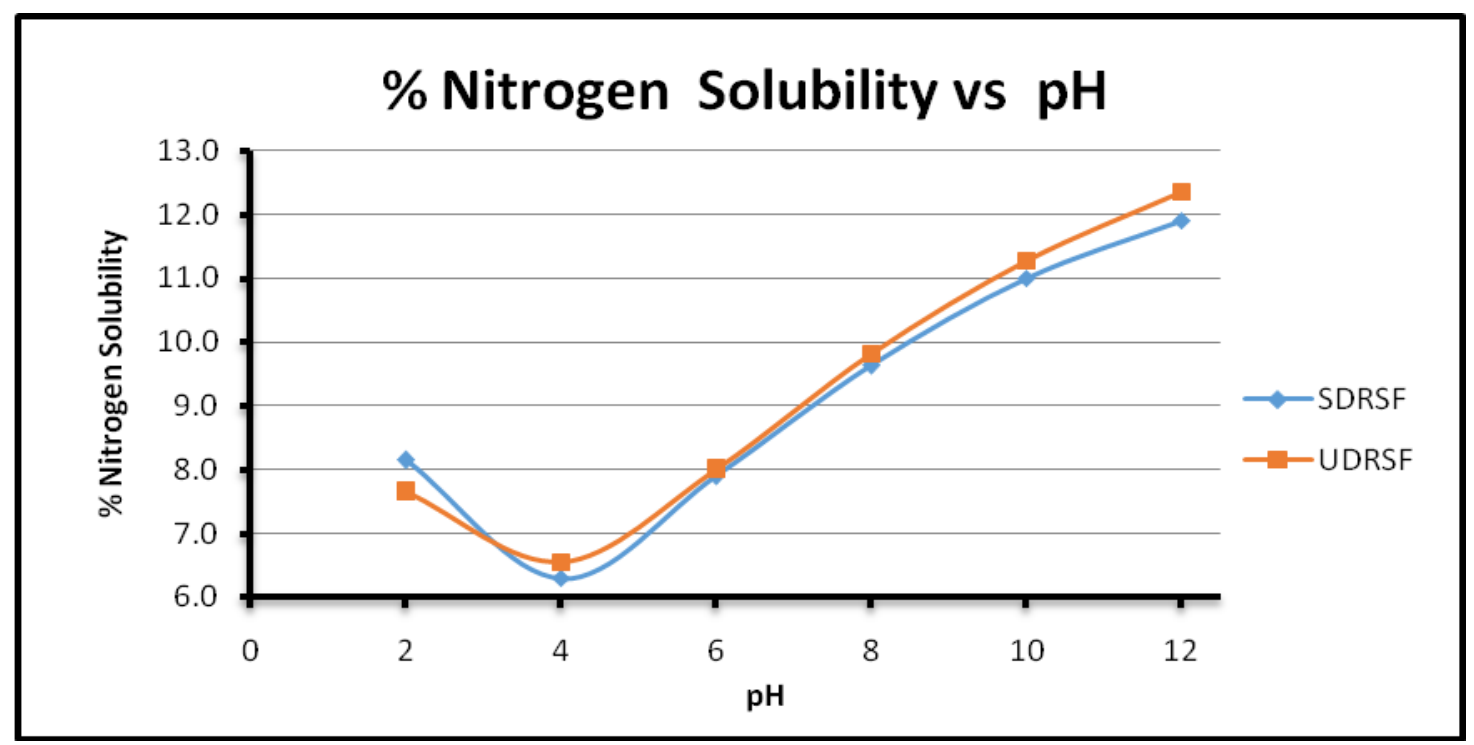

\section{Foam stability}

There was no any difference in the foam stability by various types of flours prepared from Roselle seeds.

These results showed that sprouting and decortication of Roselle seeds give good quality flour having superior functional properties which are useful for the preparation of various types of food products with good nutritional value.

\section{Sedimentation value}

Sedimentation test is a combined measure of the quantity and quality of gluten protein in wheat which is an index of wheat strength and dough-mixing characteristics. The effects of incorporating sprouted whole and sprouted decorticated Roselle seed flour in composite formulations with wheat flour was studied and the results obtained are out lined in table 3.

From the various treatment studied SWRSF recorded a higher corresponding sedimentation value compared to SDRSF, this could be as a result of the hull of Roselle seeds which contains substantial amount of insoluble dietary fiber, while inner part of the seeds accounts for soluble dietary fiber (Nyam, 2014), as the insoluble fiber in SWRSF absorbs water and increases the bulkiness of the slurry under test hence the higher sedimentation values observed.

The result obtained for both treatment falls within the 20 to 39 sedimentation values classifications (Zeleny, 1947; Table 3). The results at 10, 15, 20 and $25 \%$ levels of Roselle seed flour incorporation were significantly different $(\mathrm{p}<0.01)$ compared to control with sedimentation value (44) which falls within the range 40 to 59 for hard wheat. This shows that the composite flour under this category can be utilized as all-purpose flour for use in for bread making, cake, pastry, cookie and cracker flours. Also, the beneficial inclusion of a healthier protein enriched Roselle Seed flour and reduction of wheat protein gluten could also minimize the incidence of Celiac diseases an autoimmune disorder that results in the damage of the lining of the small intestine when food with gluten are eaten (Khaitan, 2016). The damage 
to the intestine makes it hard for the body to absorb nutrients, especially fat, calcium, iron and folate; which are vital for the sustenance our wellbeing.

\section{References}

AACC. (2000a). Approved methods of the American Association of Cereal Chemists (10th Ed.). St. Paul, MN: Author (methods 08-01, 30-25, 4415A, 46-13, 54-21, 10-50D).

AACC. (2000b). Amylograph, Farinograph and Extensograph, Approved methods of the American Association of Cereal Chemists (10th Ed.). St. Paul, MN: Author (methods No. 22-10, 54-21 and 54-10

Arshad, M. U., Anjum, F. M. and Zahoor, T. (2007). Nutritional assessment of cookies supplemented with defatted wheat germ. Food Chemistry, 102: 123128.

Bala, A., Gul, K. and Riar, C. S. (2015). Functional and sensory properties of cookies prepared from wheat flour supplemented with cassava and water chestnut flours. Cogent Food \& Agriculture, 1: 1019815.

Bambgoye, A.I. and Adejumo, O.I. (2009). Physical Properties of Roselle (Hibiscus sabdariffa L.) Seed. Agricultural Engineering International: the CIGR Ejournal. Manuscript 1154.Vol. XI.

Emmy Hainida, K.I., Amin, I., Normah, H., Norhaizan, M.E., and Ainul, Z. (2008). Effects of defatted dried roselle (Hibiscus sabdariffa L.) Seed powder on lipid profiles of hypercholesterolemia rats. J. Sci. Food Agric. 88: 1043-1050.

Emmy Hainida, K.I.; Amin, I.; Normah, H. and Mohd.-Esa, N. (2008). Nutritional and amino acid contents of differently treated Roselle (Hibiscus sabdariffa L.) seeds, J. Food Chemistry 111, 906-911.
Gunstone D.F. (2002). Vegetable Oils in food technology: Composition, properties and uses. London: Blackwell Publishing Ltd; 337pp

Karma Bako Rimamcwe and Chavan, U. D. (2016). Physical properties and nutritional potentials of Indian Roselle (Hibiscus sabdariffa L.) seeds. International Journal of Current Research. 8 (9): 38644-38648.

Karma Bako Rimamcwe and Chavan, U. D. (2017). Antioxidant Activity and Nutritional Value of Roselle Seeds Flour. Int. J. Curr. Microbiol. App. Sci (2017) 6(4): 2654-2663.

Khaitan, M. (2016). WebMD Medical Reference. Online source: www.m.webmd.com /diet/celiacdiseases.

Makri, E., Papalamprou, E. and Doxastakis, G. (2005). Study of functional properties of seed storage proteins from indigenous European legume crops (lupin, pea, and broad bean) in admixture with polysaccharides. Food Hydrocolloids. 19: 583-594.

Myfolia.com (2016), online source: https://myfolia.com

Narayana, K. and Rao, M.S.N. (1982). Functional Properties of Raw and Heat Processed Winged Bean (Psophocarpus tetragonolobus) Flour. Journal of Food Science, Vol. 47, issue 5, pp. 15341538.

Nyam KL, the YN, Tan CP and Kamariah, L., (2012). In vitro Antioxidant Activities of Extract and Oil from Roselle (Hibiscus sabdariffa L.) Seed against Sunflower Oil Autoxidation, Mal J Nutri 18(2): 265-274.

Nyam, Kar-Lin; Leao, Sod-Ying; Tan, ChinPing; and Long, Kamariah (2014). Functional Properties of Roselle (Hibiscus sabdariffa L.) seed and its application as bakery product, J. Food Sci. Technol 51(12):3830-3837. Doi: 
10.1007/s13197-012-0902-x

Nzikou, J.M., Bouanga-Kalou, G., Latos, L., Ganongo-Po, F.B., Mboungou-Mboussi, P.S., Moutoula, F.E., Panyoo-Akdowa, E., Silou, T.H., and Desobry, S. (2012). Characteristics and Nutritional Evaluation of Seed oil from Roselle (Hibiscus sabdariffa L.) in CongoBrazzaville, Current Research Journal of Biological Sciences 3(2): 141-146.

Okafor, J. N., Ozumba, A. U. and Solomon, H. M. (2002). Production and acceptability of chinchin fortified with oyster mushroom. Nigeria Food Journal, 18: 19-20.

Panse, V.G. and Sukhatme, P.V. (1985). Statistical methods for Agricultural Workers. $4^{\text {th }}$ ed., New Delhi

Platon, JF. (1997). Lipids in Cosmetology. Ol. Corps Gras Lipid; 4: 275-281.

Ramadan M.F. and Morsel J.T. (2004). Oxidative stability of black cumin (Nigella sativa L.), coriander (Coriandrum sativum L.) and Niger (Guizotia abyssinica Cass.) crude see Ad oils upon stripping. Eur J Lipid Sci Technol; 106: 35-43.

Rosell, C.M., Santos, E. and Collar, C. (2009). Physico-chemical properties of commercial fibres from different sources: a comparative approach. Food Res. Int. 42:176-184

Salunkhe, D.K., Chavan, J.K., Adsule, R.N., Kadam, S.S. (1992). World Oil Seeds Chemistry, Technology and Utilization, Pub. By Van Nostrand Reinhold, New York, P. 35

Vasquez-Ovando, A., Rosado-Rubio, G., Chel-Geurrero, L. and BatancurAncona, D. (2009). Physicochemical properties of fibrous fraction from chia (Saliva hispanica L.). J. Food Sci. Technol 42:168-173

Wani, S. H., Gull, A., Allaie, F., \& Safapuri, T. A. (2015). Effects of incorporation of whey protein concentrate on physicochemical, texture, and microbial evaluation of developed cookies. Cogent Food \& Agriculture, 1: 1092406.

Yayock, J.Y., Lombin, G. and Owonubi, J.J. (1988) Crop Science and Production in Warm Climates. Macmillan Publishers, London, p.307

Zeleny, Lawrence (1947). A Simple Sedimentation Test for Estimating the Bread-Baking and Gluten Qualities of Wheat Flour. Cereal Chem, 24(6): 465 -475 .

\section{How to cite this article:}

Karma Bako Rimamcwe, U.D. Chavan, G.H. Pawar and Gaikwad, R.S. 2017. Nitrogen Solubility and Functional Properties of Roselle Seed Flour. Int.J.Curr.Microbiol.App.Sci. 6(8): 1131-1139. doi: https://doi.org/10.20546/ijcmas.2017.608.140 